\title{
Peru, 2002-2012: growth, structural change and formalization
}

\author{
Juan Chacaltana
}

ABSTRACT

\begin{abstract}
In a dramatic change of trend, labour formalization took place in Peru in the period covered
by this study. The context was one of economic growth accompanied by a labour market reform that created a special regime for micro and small enterprises, thereby reducing employment costs, and introduced improvements in workplace inspections. A panel of subnational regions is used to analyse the role played by these factors in the formalization process. In the first place, this study confirms that the composition of growth matters to formalization. A combined analysis of economic factors (growth and sectoral growth) and recent institutional changes shows that the former accounted for the bulk of formalization in the period analysed and that growth in labour-intensive sectors adds explanatory power, while the institutional changes, far-reaching though they were, did not have a significant effect.
\end{abstract}

KEYWORDS

JEL CLASSIFICATION

AUTHOR
Economic growth, employment, labour market, informal sector, econometric models, case studies, labour policy, Peru

J08, J46, 017, 040

Juan Chacaltana is a specialist in Labour Economics with the International Labour Organization (ILO) Regional Office for Latin America and the Caribbean. 


\section{I}

\section{Introduction}

The early years of the twenty-first century were exceptional ones for the Peruvian economy: gross domestic product (GDP) grew at an annual rate of over $6 \%$ for more than a decade (except in the crisis period of 2008-2009), which is practically unprecedented for the country. From 2002 to 2013, in fact, Peru ranked second for growth in Latin America.

Certain social and economic indicators were dynamized during this period. For example, poverty fell by more than half between 2002 and 2013, from $54 \%$ to $24 \%$, declining even in rural areas. Some labour market indicators also moved positively. In 2013, open unemployment fell to less than $4 \%$ nationally, the lowest value recorded in Peruvian statistics for some decades. Between 2002 and 2013, total employment rose by $2.4 \%$ a year, outstripping the growth in the working-age population ( $1.8 \%$ a year). Urban real wages rose at a rate of $3.6 \%$ a year and social security health-care coverage climbed from $30 \%$ to $59 \%$. $^{1}$

Probably the most significant change was that the proportion of workers in formal employment rose from $20.1 \%$ in 2007 to $26.3 \%$ in 2013 , according to official data from the National Institute of Statistics and Informatics (INEI, 2014). While the rate is still quite low, this six percentage point increase is striking, as it means that formal employment grew by far more than overall employment in the period. Another indicator of formalization is registered employment nationwide, calculated by the Ministry of Labour and Employment Promotion (MTPE). ${ }^{2}$ This also grew continuously from 2002 , following a period of relative stagnation in the late 1990s. This represents a change of trend from earlier decades, when informality usually increased regardless of economic circumstances.

\footnotetext{
$\square$ The opinions expressed in this article are the author's and do not necessarily reflect those of the International Labour Organization (ILO). The author is grateful for the valuable comments and suggestions of Janina León, Gustavo Yamada, Gabriel Rodríguez, Jorge Rojas, Patricia Tovar, Rodolfo Cermeño, Ricardo Infante, Jorge Bernedo, Phillipe Marcadent, Rosalía Vásquez-Álvarez, Juan Manuel García, Claudia Ruiz and Florencio Gudiño on an earlier version. Any errors or omissions are the author's alone.

${ }^{1}$ ILO (2014). Includes non-contributory and semi-contributory regimes.

2 The registered employment index shows the behaviour of wage employment in firms with 10 or more workers. It is calculated on the basis of the National Monthly Survey on Employment Variation (ENVME).
}

Very little has been written about formalization in developing countries with high levels of informality like Peru. The academic literature and discussion have concentrated primarily on analysing informality. Furthermore, almost everything that is known about formalization in Peru is based on theories or studies preceding specific interventions, and little on evaluations of these. The present article offers an ex post analysis of two major institutional changes: the creation of the special employment regime for micro and small enterprises, and the improvements to the workplace inspection system. In other words, it analyses formalization in a specific period to identify explanatory elements and draw lessons, and asks a number of questions. What caused formalization to change trend and rise in Peru? Was it the result of high growth rates or of the labour market reform, which created a special employment regime for micro and small enterprises, substantially reducing labour costs in most of the wage employment market? In particular, what role was played by the sectoral composition of growth and by the major institutional changes that occurred in the same period? This study analyses all these factors jointly, seeking to identify the relative contribution of each to the formalization seen in the different regions. This process is recent in Peru, and it offers a unique opportunity to apply a comparative analysis to opposing theories about formalization. This analysis will provide a basis for consolidating and enhancing formalization policies or strategies as part of an integrated or multidimensional approach. ${ }^{3}$

The article is organized as follows. The second section reviews the existing literature on the causes of informality and its different determinants. The third section analyses recent economic and institutional changes in Peru that may have contributed to formalization, using subnational regions as units of analysis during 2002-2012. The fourth section carries out an econometric estimate to quantify the determinants of the formalization process. Lastly, the fifth section presents the conclusions of the study.

\footnotetext{
3 Other reforms may have contributed to formalization in Peru, particularly policies to promote micro, small and medium-sized enterprises and reforms to simplify bureaucratic procedures. Evaluating such policies is beyond the scope of this article, however.
} 


\section{II}

\section{Literature review}

For more than four decades since the concept of informality was first proposed in the early 1970s (Hart, 1972), there has been a great deal of discussion of its causes around the world but no consensus when it comes to defining or even measuring it. ${ }^{4}$ This lack of conceptual consensus undoubtedly explains the disparate emphases of the various policy recommendations.

An array of theoretical approaches or frameworks have been developed and put forward to account for informality. ${ }^{5}$ In a first group of studies, it is connected to economic factors, especially the lack of production development, the characteristics of this, or both. Thus, a position is taken whereby the only thing that matters for economic development is the level of growth, with particular emphasis on physical capital accumulation. ${ }^{6}$ The best-known implication of these models is that there should eventually be convergence between countries, although the empirical literature has not borne out this prediction. Another approach maintains that the composition of growth is also important, since it can be uneven across sectors, mainly because of the composition of demand (Ray, 2010).

One prominent variant of this second position is the dualistic approach, whereby economic change is determined not only by the level of growth, but also by the transfer of productive resources from a subsistence sector to a capitalist sector (Lewis, 1954). Doeringer and Piore (1971) argue that there is a sector of "good" jobs and one of "bad" jobs. Acemoglu (2001) additionally proposes a job-seeking model in which there are good and bad jobs.

Another variant is the changing production patterns or structural change approach, whereby technical progress is not introduced evenly across all sectors and branches of activity, tending rather to be concentrated in certain production sectors and strata, especially exporting ones, with large sectors of the economy being left out of this

\footnotetext{
${ }^{4}$ Kanbur (2009) says that the literature on the subject is in a mess, there is a "conceptual incoherence" to it and everyone uses a different definition.

5 Numerous studies have tried to classify the different approaches. See, for example, WIEGo (2012).

${ }^{6}$ Solimano (1996) associates this way of thinking first and foremost
} with the neoclassical school. modernization process. This state of affairs is known as "structural heterogeneity," and it encompasses productivity differences between sectors, their contribution to GDP and the volume of employment they generate. Heterogeneity exists between but also within sectors, between production strata and, most especially, between firms of different sizes. The continuing employment of a large section of the workforce in low-productivity sectors or strata is a considerable source of inequity in income distribution among those in work, and also explains informality in employment (Infante and Sunkel, 2012). These authors also stress that production heterogeneity by business stratum (firm size) is the core from which inequality spreads through society.

Some authors emphasize the role of agriculture in promoting structural change (De Janvry and Sadoulet, 2010). Others stress the role of manufacturing growth as an engine of employment and productivity (Kaldor, 1961; Chang, 2007). There are also authors who assert that a dynamic services sector can mean more inclusive growth because it is labour-intensive, especially when seconded by policies to boost education and employment. Bhagwati and Panagriva (2013) add that modern services can be technologically progressive to a high degree, with the retail, financial and telecommunications sectors, for example, working with modern technologies. There is also a large literature exploring the effects of natural resource-based growth. McMillan and Rodrik (2011) argue that heavy dependence on natural resources for exports makes the repercussions of structural change on labour productivity very much smaller. Conversely, growth in more labour-intensive sectors and in manufacturing will generate more employment in middle-income countries.

There is also the possibility that there may be interrelationships between the formal sector and the formal sector. Tokman (1978) explores the nature of these interrelationships and finds that the informal sector and the modern sector are not watertight compartments, but that there are very active communicating vessels in both the product and labour markets. In the case of Peru, León and Cermeño (1990) review the main propositions advanced regarding the interrelationships between the formal and informal sectors in that country and Latin America generally. Analysing the case of manufacturing 
microenterprises in Lima, these authors find that all microenterprises, but particularly manufacturing ones, are highly interrelated with the rest of the economy, and especially with the modern production sector (through procurement of inputs) and with final consumers (who are their main customers, especially those in low-income strata). Portes, Castells and Benton (1989) offer a picture in which informal sectors are integrated with modern ones via the decentralization of production, in particular local and international subcontracting, with subcontractors employing workers who are not covered by employment legislation with a view to holding down costs and thus being able to sell cheaply.

A second group of explanations deal with institutional factors. Foremost among them is the well-known legalitybased approach of De Soto and others (1986), originally developed in consideration of the situation in Peru. This approach points out that informal workers are forced by lack of capital and by inadequate demand for formal labour and the high costs in money and time of the long and cumbersome procedures involved in setting up a formal enterprise to operate with very limited resources and at very low levels of productivity and income. Furthermore, these workers usually do not hold title to their land, properties and productive assets, so that they have no access to the financial system. On this view, informal workers represent development potential, and the deregulation of bureaucratic procedures and obstacles is essential for this to be released.

A variant of this approach is one that treats informality as resulting from a voluntary decision by the worker or business owner, who decides to operate outside of the legal rules following a comparative analysis of the benefits and costs of formality in respect of registration, taxation, wages and social security, among other things (Fields, 1990; Perry and others, 2007; Maloney, 1999). In the case of Peru, Yamada (1996) finds evidence of voluntary choice among the informal self-employed. Similarly, Levy (2008) adds that the existence of social protection programmes, especially non-contributory ones, could create incentives to opt for informality.

Another approach, also centred on institutions, focuses on the weakness of public administration, with particular reference to inspection and oversight systems and corruption. Kanbur (2009) emphasizes the need for a theory of law enforcement, a subject of great importance in Latin America, where laws are often passed but not enforced. Loayza (2013) lists the following as determinants of informality: the government's ability to enforce rules (law and order index), an index of economic freedom as a proxy for restrictions imposed by the legal and regulatory framework, average years of schooling as a proxy for the development of education, workforce skills, an index of sociodemographic variables and the agricultural share of GDP.

Naturally, each line of thought leads to different and even opposing policy conclusions and recommendations. Fortunately, recent decades have seen progress in this discussion that has brought a degree of consensus. In 1993, the fifteenth International Conference of Labour Statisticians (ICLS) defined the scope of the concept of the "informal sector" and associated it with the characteristics of the economic unit. ${ }^{7}$ Subsequently, in 2003, the seventeenth ICLS supplemented this definition and introduced the concept of "informal employment," based on job characteristics. ${ }^{8}$ Combining the two concepts yields the so-called "informal economy" (ILO, 2002). This means, however, that informal employment exists not just in the informal sector but also outside it, although the relative weight of each of these components differs from country to country. Furthermore, it is clear that the policies applicable to informal employment in the informal sector are different from those for informal employment outside it.

This, along with overwhelming international evidence that informality is highly heterogeneous, has opened up the possibility of approaching formalization policies in a broader way. In its 2014 and 2015 discussions, the International Labour Conference (ILC) proposed an integrated approach to facilitate the transition from informality to formality. These discussions led to the adoption of the Recommendation concerning the transition from the informal to the formal economy (ILO, 2015), marking the start of a global consensus on policy recommendations. This entails a recognition that informality is so heterogeneous that all the factors which might be thought to cause it must play some kind of role, that not all informal workers are in this situation for the same reason, and that the causes of informality are many and operate in multiple dimensions. For this reason, any formalization policies devised need to take a multidimensional approach that involves numerous actors operating in coordination. Looking at the matter in this way shows how limiting it is to think that any single or isolated measure can foster formalization in

\footnotetext{
7 This concept differs from that of the "informal sector," much used in Latin America by the Regional Employment Programme for Latin America and the Caribbean (PREALC) and referring to low-productivity forms of production, including smaller firms, unskilled own-account workers and domestic work.

${ }^{8}$ See ILO (2013) for a fuller discussion.
} 
all countries and circumstances. Another implication is that the different factors leading to formality differ between countries, territories and sectors. In other words, the ultimate determinants of informality (or formality) in a specific country have to be established empirically and not theoretically, according to the circumstances of each case. In particular, there is a need to establish empirically and case by case which of the factors associated with formality (or informality) have greater influence than others.

\section{III}

\section{Stylized facts, the Peruvian case}

Peru has always been regarded as a country with a high level of informality. According to official data from the National Institute of Statistics and Informatics (INEI, 2014), which prepares an informal economy satellite account for Peru, ${ }^{9}$ the informal sector, measured by the characteristics of economic units, accounted for $19 \%$ of GDP and $61 \%$ of total employment in 2007. ${ }^{10}$ Informal employment, which includes such employment in the informal sector but also in the formal sector and the household sector, was $73.7 \%$ nationally in 2013 . The information on informal employment in Peru is obtained from the National Household Survey (ENAHO), which shows that about two in every three workers in informal employment work in economic units in the informal sector.

\section{Formalization in Peru?}

Almost all academic studies on this subject in Peru have sought to explain the phenomenon of informality, and in particular its unremitting rise. ${ }^{11}$ They could hardly do otherwise. In past decades, the rule has been for informality to increase in the Peruvian labour market. ${ }^{12}$ Thus, the start of a movement towards formalization

\footnotetext{
${ }^{9}$ See INEI (2014). This informal economy satellite account is consistent with the country's System of National Accounts. Informal employment is estimated in equivalent working days to ensure compatibility with the national accounts (period from 2007 to 2013).

10 There are other estimates of the informal sector contribution to GDP, but they use indirect methods. The INEI approach is direct. If these figures are right, the formal sector is eight times as productive as the informal sector

${ }^{11}$ Chong, Galdo and Saavedra (2007) record a persistent increase in informality in 1986-2001, using different definitions of informality.

12 Unlike the analysis of informality, the study of formalization processes has only recently become a subject of academic interest internationally. See Berg (2010) on Brazil, and Bertranou, and Casanova (2014) on Argentina.
}

has probably been the most striking development in that labour market in recent years, marking a shift in a long-term trend that is worth analysing.

Different indicators confirm this change in trend (see figure 1). First, as noted, official INEI data for urban and rural workers in all economic sectors nationally show the proportion in formal employment rising from $20 \%$ in 2007 to $26 \%$ in 2013 (left axis of figure 1). Likewise, the index of registered employment calculated by MTPE since 1997 shows such employment growing constantly from 2002 (right axis of figure 1) after holding fairly steady in the late 1990s and early 2000s. ${ }^{13}$ Other data from administrative records are even more encouraging. Social security records show that the number of duespaying members of the social health insurance programme (EsSalud) rose from 1.6 million in 2002 to 4.3 million in the last quarter of 2013, while the number paying into some pension scheme rose from 1.5 million in 2002 to 4.0 million in 2013. Again, the number of registered payroll workers rose from less than a million in 2000 to 3.1 million in 2013.

Estimates prepared by the author using a methodology similar to that of INEI but for a longer period (2002-2012) $)^{14}$ show that the increase in the formal employment rate occurred primarily among wage workers, for whom it rose from $41 \%$ to $50 \%$ between those years (see table 1 ). This trend is very important, as the proportion of wage workers in the employment total also rose in the period,

\footnotetext{
13 The index of registered employment shows the behaviour of wage employment in firms with 10 or more workers. It is calculated from the National Monthly Survey on Employment Variation (ENVME).

${ }^{14}$ Methodology based on the measuring guidelines of the seventeenth International Conference of Labour Statisticians (ILO, 2013). The difference from the INEI (2014) estimate stems from the latter being based on the equivalent number of jobs (calculated from the length of working days) to ensure compatibility with the System of National Accounts.
} 
from $39 \%$ to $45 \%$. Among such workers, the largest increase in the formal employment rate was for those in firms with more than 10 employees, where it rose from $61 \%$ to $71 \%$, with this group's share of total employment additionally moving up from $23 \%$ to $29 \%$. In the case of smaller firms, the increase in the formal employment rate was from $13 \%$ to $15 \%$, while their share of total employment rose from $16 \%$ to $17 \%$.

FIGURE 1

Peru: official indicators of formalization

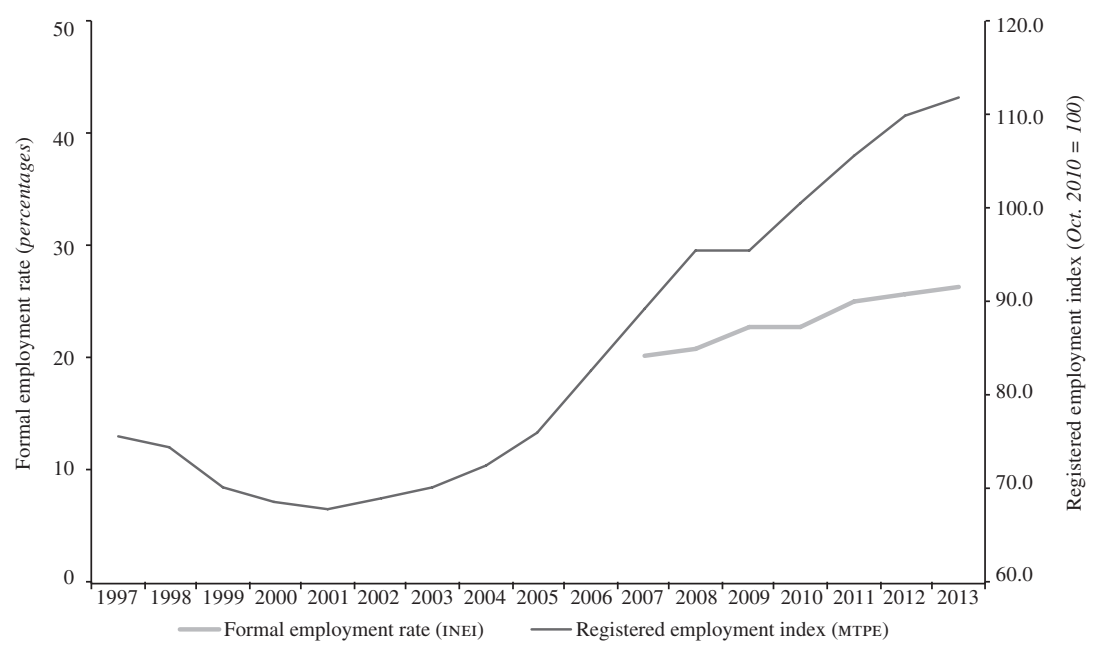

Source: Prepared by the author, on the basis of National Institute of Statistics and Informatics (INEI), Producción y empleo informal en el Perú. Cuenta satélite de la economía informal 2007-2012, Lima, 2014, and statistics from the Ministry of Labour and Employment Promotion (MTPE).

TABLE 1

Peru: formal employment rates, 2002 and 2012

(Percentages)

\begin{tabular}{|c|c|c|c|c|}
\hline & \multicolumn{2}{|c|}{2002} & \multicolumn{2}{|c|}{2012} \\
\hline & Formal employment rate & $\begin{array}{l}\text { Share of total } \\
\text { employment }\end{array}$ & $\begin{array}{c}\text { Formal } \\
\text { employment rate }\end{array}$ & $\begin{array}{l}\text { Share of total } \\
\text { employment }\end{array}$ \\
\hline \multicolumn{5}{|l|}{ Total } \\
\hline Employer & 34.1 & 5.1 & 39.9 & 5.4 \\
\hline Wage employee in firm & 40.7 & 39.1 & 50.1 & 45.4 \\
\hline 1 to 10 & 12.7 & 16.3 & 15.2 & 16.7 \\
\hline Over 10 & 60.9 & 22.7 & 70.5 & 28.7 \\
\hline Wage employee in household & 10.0 & 3.5 & 19.3 & 2.6 \\
\hline Own account & 4.3 & 35.4 & 4.6 & 34.8 \\
\hline Auxiliary family worker & 0.0 & 16.7 & 0.0 & 11.6 \\
\hline Other & 21.3 & 0.2 & 16.3 & 0.3 \\
\hline Total & 19.6 & 100.0 & 27.1 & 100.0 \\
\hline
\end{tabular}

Source: Prepared by the author, on the basis of National Institute of Statistics and Informatics (INEI), National Household Survey (ENAHO), various years.

Informal employment among wage employees carrying out domestic work in households also evolved significantly, with their formal employment rate rising from $10 \%$ to $19 \%$, even as their share of total employment dropped from $4 \%$ to $3 \%$. In the case of own-account workers, the formal employment rate rose from $4.3 \%$ to $4.6 \%$ while their share of total employment remained unchanged at $35 \%$. These changes still left own-account 
workers, workers in firms with up to 10 employees and domestic workers accounting for over two thirds of total informal employment.

The fact that the rise in formal employment has involved mainly wage employees rather than own-account workers highlights the differences between the causes of informality and the policy responses required in the two cases. It also suggests that the situation of each group needs to be analysed separately.

\section{Recent economic and institutional changes}

Some economic and institutional changes may be connected to this shift in the formalization trend.

The first thing that stands out is the strong economic growth attained by the Peruvian economy, precisely since 2002. One of the main debates in the literature on informality concerns its procyclical or countercyclical character. If it were countercyclical, there would be reason to think it was a kind of adjustment "cushion" against a lack of opportunities in the formal sector. If there were procyclical elements, voluntary choice might be involved. In the recent Peruvian situation, economic growth has been high and sustained, averaging $6.1 \%$ between 2002 and 2013. This stands in contrast to earlier decades, as the Peruvian economy grew by about $3 \%$ a year in the 1990s and hardly at all in the 1980s. Recent Peruvian growth has been associated mainly with a highly favourable international context, owing partly to high export commodity prices and improved terms of trade, partly to the availability of external financing and foreign direct investment (FDI). It has also been related to macroeconomic policies, such as inflation targeting in monetary policy, the build-up of international reserves, exchange-rate flexibility and countercyclical fiscal policies (MEF, 2011). Productivity, one of the variables most emphasized in discussions of formalization, grew by $3.3 \%$ a year in 2000-2011 (Infante, Chacaltana and Higa, 2014). Although not as high as the rate in some Asian countries over the period, this was among the highest in Latin America and the Caribbean. ${ }^{15}$

In the second place, a connection is often made between the sectoral composition of growth and informality, and thence formalization. This is due to the existence of a high degree of productive heterogeneity in the Peruvian economy, manifested both between and within sectors. Indeed, elevated heterogeneity and productivity dispersion may be the most salient structural characteristic of the Peruvian economy, combined with manifest delinkage between the most and least productive sectors. This can clearly be seen in table 2 , which shows that in 2007 the sector with the highest productivity (mining) was 50 times as productive as the one with the lowest (farming and fishing).

15 Greater uncertainty in the international context is expected over the coming years, and the effects this change could have on the country's growth rates are currently being discussed. There is some consensus, for example, that the prices of commodities relevant to Peru (particularly copper) will not rise in the same way or to the levels seen in the last decade.

TABLE 2

Peru: structure of production and employment in the informal and formal sectors, 2007

\begin{tabular}{|c|c|c|c|c|c|}
\hline & \multirow{2}{*}{$\begin{array}{l}\text { GDP share of the } \\
\text { informal sector } \\
\qquad \%)\end{array}$} & \multirow{2}{*}{$\begin{array}{l}\text { Employment share } \\
\text { of the informal sector } \\
(\%)\end{array}$} & \multicolumn{3}{|c|}{ Labour productivity (2007 nuevos soles) } \\
\hline & & & Total & Formal & Informal \\
\hline Other services (inc. government) & 6 & 13 & 27714 & 29944 & 12791 \\
\hline Manufacturing & 13 & 39 & 30141 & 42988 & 10047 \\
\hline Mining & 2 & 30 & 224961 & 314945 & 14997 \\
\hline Commerce & 32 & 65 & 11910 & 23139 & 5863 \\
\hline Transport & 37 & 73 & 23807 & 55549 & 12066 \\
\hline Farming and fishing & 89 & 98 & 4620 & 25411 & 4196 \\
\hline Construction & 25 & 54 & 23820 & 38838 & 11028 \\
\hline Restaurants and hotels & 47 & 67 & 8955 & 14382 & 6282 \\
\hline
\end{tabular}

Source: Prepared by the author, on the basis of National Institute of Statistics and Informatics (INEI), Producción y empleo informal en el Perú. Cuenta satélite de la economía informal 2007-2012, Lima, 2014.

Note: GDP: Gross domestic product; Inc. government: Includes government-provided services. 
Differences within sectors are also striking: productivity is 15 times as great in formal mining as in informal mining. Figure 2 also shows that, mining aside, the most productive part of the informal sector (Other services) is less productive than the least productive part of the formal sector (Restaurants and hotels). This is indicative of a divided country and an uninclusive production structure with the potential to generate informality. ${ }^{16}$

16 Távara, González de Olarte and Del Pozo (2014) analyse the heterogeneity of the Peruvian economy over the long term and find
Where trends are concerned, the official production data reveal changes in the composition of growth (see table 3). In the period prior to 2002, growth rates were very high in sectors such as mining, even in the period of international crisis that began in 1998. This composition began to change in 2003, with stronger growth in sectors such as manufacturing and construction.

that this has increased in both growth and crisis periods. They also find that most services (financial and non-financial) are produced and consumed by the large enterprise sector. The same is true of energy.

FIGURE 2

Peru: productive heterogeneity in the formal and informal sectors, 2007

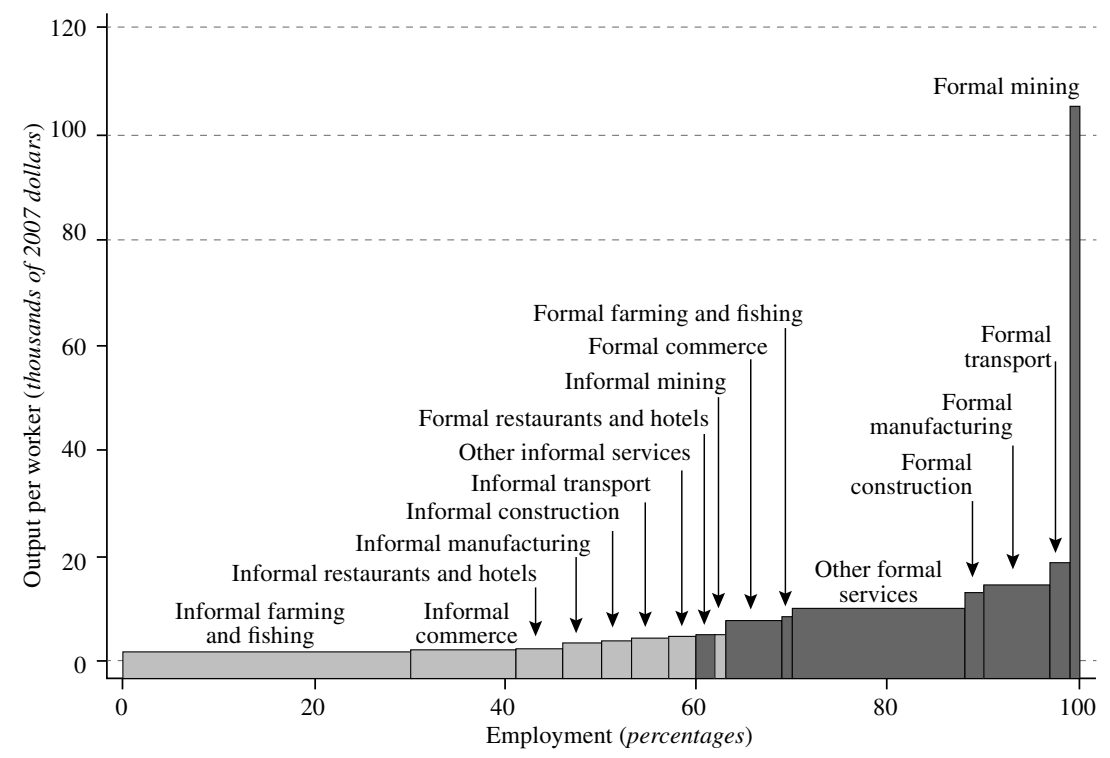

Source: Prepared by the author, on the basis of National Institute of Statistics and Informatics (INEI), Producción y empleo informal en el Perú. Cuenta satélite de la economía informal 2007-2012, Lima, 2014.

TABLE 3

Peru: average annual GDP growth by economic sector, four periods between 1993 and 2012

(Percentages)

\begin{tabular}{lcccc}
\hline & $1993-1997$ & $1998-2002$ & $2003-2007$ & $2008-2012$ \\
\hline Farming, hunting and forestry & 8.4 & 4.7 & 3.7 & 4.9 \\
Fisheries & 0.2 & 3.0 & 5.8 & 0.5 \\
Mining & 8.1 & 8.1 & 4.6 & 2.2 \\
Manufacturing & 6.3 & 1.5 & 7.4 & 4.4 \\
Electricity and water & 8.7 & 3.9 & 5.8 & 5.9 \\
Construction & 16.2 & -3.3 & 9.7 & 7.4 \\
Commerce & 7.6 & 0.8 & 7.2 & 7.5 \\
Transport and communications & 6.8 & 1.4 & 9.5 & 8.0 \\
Restaurants and hotels & 6.4 & 0.9 & 5.7 & 6.7 \\
Other services & 4.9 & 1.5 & 5.5 & 6.5 \\
Total & 6.9 & 1.8 & & 6.4 \\
\hline
\end{tabular}

Source: Prepared by the author, on the basis of national accounts from the National Institute of Statistics and Informatics (INEI).

Note: GDP: Gross domestic product. 
Fewer data are available on changes in composition within sectors. Even so, some studies have provided evidence of their scale. Infante, Chacaltana and Higa (2014) estimate that of the $3.3 \%$ annual productivity growth in the 2000-2011 period, $2.8 \%$ was due to large enterprises (with over 200 workers) and the remaining $0.5 \%$ to micro, small and medium-sized enterprises. Tello (2012) analyses the behaviour of productivity in 20022007 and finds that it is the reallocation of employment between sectors rather than productivity changes within them that best explains shifts in Peruvian productivity.

Major institutional changes also took place in the last decade. The most important of these was probably the reform that created special employment regimes, i.e., specific regulations for certain groups of workers. By far the most salient development here was the creation of the special employment regime for micro and small enterprises under the Promotion and Formalization of Micro and Small Enterprises Act. ${ }^{17}$ There had already been reforms in the 1990s to the rules on hiring and dismissal in the general employment regime. ${ }^{18}$ The creation of special regimes is a new regulatory trend beginning essentially after the turn of the century. For workers in microenterprises (up to 10 workers), the Act, passed in 2003, drastically cut non-wage costs to less than a quarter, and dismissal costs to a third, of the amounts stipulated in the general regime. ${ }^{19}$ In 2008 , the special regime of the Act was extended and an intermediary regime was set up for firms with up to 100 workers, cutting employment costs to about half what they were under the general regime. ${ }^{20}$ This new dispensation came into effect in early 2009.

Given that microenterprises account for over $70 \%$ of wage employment in Peru, these reforms meant a very large shift in average employment costs (see figure 3). In weighted terms, so-called non-wage labour costs fell from $54 \%$ of wages to $17 \%$ in $2003 .{ }^{21}$ Despite their

\footnotetext{
17 The Agriculture Promotion Regime, which likewise includes the special employment and tax regimes, applying these to agricultural enterprises of any size, was created in 2000. See Chacaltana (2007) for further information.

${ }^{18}$ Chacaltana (2001) finds that the labour market reforms of the 1990s, which deregulated hiring and dismissal, were not accompanied by improvements in formalization.

19 There is a debate about the concept of "non-wage costs," with some considering holiday pay, for example, to be part of wages.

${ }^{20}$ Calculated from Law No. 30288, published in the official journal El Peruano (16 December 2014).

21 This regime was extended yet further in 2013 and the legal ceiling on the number of workers abolished. The calculations were carried out using data from Law No. 30288, published in the official journal El Peruano (16 December 2014).
}

reach, these regimes have been little studied. Chacaltana (2008) analyses the first four years of the microenterprise regime and finds coverage to be minimal. Jaramillo (2013) reaches similar conclusions, while Díaz (2014) adds that the formalization of recent years took place to a greater extent in the large enterprise sector than among small and medium-sized enterprises.

Lastly, another factor in formalization is the ability of the State to enforce its own rules. ${ }^{22}$ Peru's inspection capability has always been considered, and has in fact been, weak. Nonetheless, there were major changes in the last decade. The strength of the State to enforce its rules is shown by the likelihood of breaches of employment regulations being detected. This depends on the number of inspectors, on the technology used to carry out inspections, and on the way these are organized. There have been improvements in all these areas. The number of inspectors has increased, but most importantly there have been changes in inspection technology. In 2006, an agreement was signed between the Ministry of Labour and Employment Promotion and the Office of the National Superintendent of Tax Administration (SUNAT), setting up an electronic payroll system. In Peru, firms are required to send in their payrolls to the State, including information on workers, wages, contract type and other benefits. Prior to the agreement, firms had to physically submit print-outs of their payrolls once a year to the MTPE. With the electronic payroll system, these have to be submitted to SUNAT monthly along with the firm's tax return. Since sunAt has demonstrated a stronger inspection capability than MTPE, this ought to have meant an increase in the likelihood of infractions being detected, at least as far as the SUNAT remit runs. ${ }^{23}$

There may possibly be other factors at work, but these are the ones most mentioned or emphasized in the academic and political discussion in Peru. Just a few studies have carried out combined analysis of multiple factors relating to formality (or informality), ${ }^{24}$ as most have concentrated on just one. Indeed, it is possible that each taken separately may present some degree of correlation and significance. The challenge is to see if these still persist in a comparative analysis, controlling for other possible explanations.

22 Kanbur (2009) mentions that the issue of enforcement has been neglected in the economic literature and a theory about it is needed.

${ }^{23}$ The electronic payroll information is available to the inspectorate.

${ }^{24}$ See, for example, Machado (2012), Loayza (2013) and Verdera (2014). 


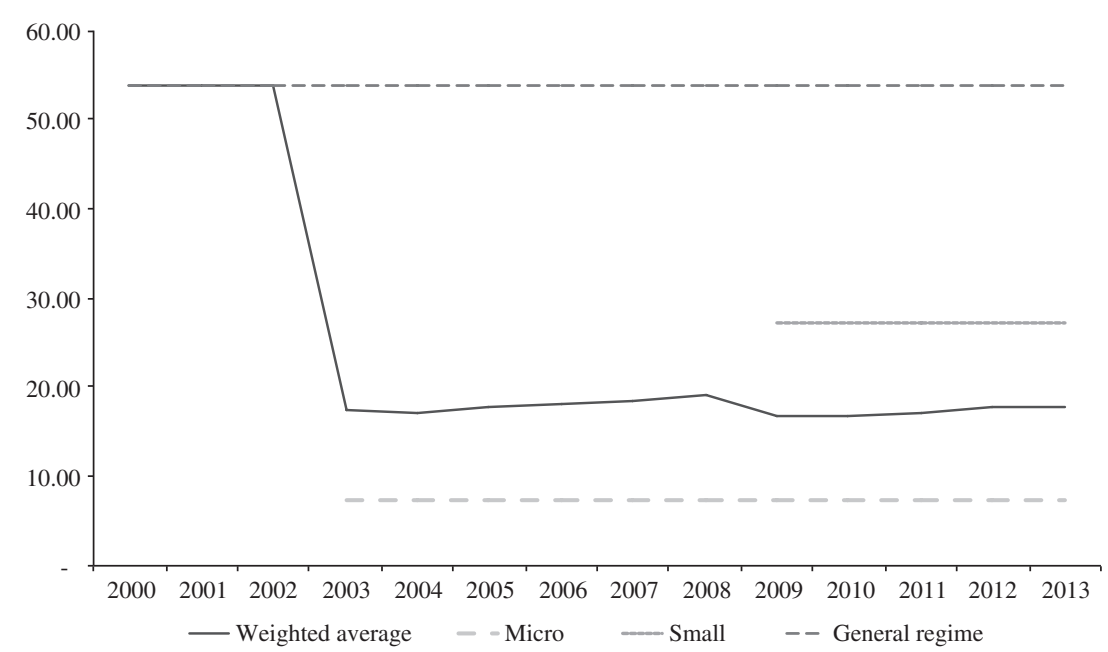

Source: Prepared by the author, on the basis of the official journal El Peruano, "Ley N ${ }^{\circ} 30288$ ", 16 December 2014, and of National Institute of Statistics and Informatics (INEI), National Household Survey (ENAHO), various years.

Note: The weighted average was calculated by taking the proportions of workers by firm size and non-wage costs likewise by firm size.

\section{IV}

\section{Empirical analysis 25}

This section seeks to explain the increase in formalization in Peru between 2002 and 2012 at the region level. In a first stage, the relationship between formalization and economic growth is analysed, with a particular focus on the role of its composition, i.e., the growth of each economic sector in each region. In a second stage, besides economic growth and sectoral growth, a proxy for institutional reforms is included with a view to establishing their relative contribution.

Panel-type information for the country's 24 regions and the 11-year time period covered is available for this purpose. With a view to analysing the role played by the composition of economic growth by sector, the panel also includes information on value added per worker for eight economic sectors in each region (Farming and fishing, Mining, Manufacturing, Construction, Commerce, Transport and communications, Restaurants and hotels, and Other services, which encompass government administration and social services). ${ }^{26}$

\footnotetext{
25 Unless otherwise indicated, the fourth section uses information on the registered employment rate from the MTPE National Monthly Survey on Employment Variation (2002-2012) for the econometric exercise.

${ }^{26}$ Regional value added is regional GDP minus taxes and import duties,
}

Different indicators can be employed to measure formality. Unless otherwise stated, the registered employment rate for each region is used, this being defined as the percentage of the region's total workforce that workers reported by firms represent. ${ }^{27}$ Information is available for 15 regions in 2002-2007 and for all regions from 2008 to 2012. This is therefore an unbalanced panel.

The information on production and its sectoral composition was obtained from the Compendio estadístico del Perú (INEI, 2013), which yields a total of 264 observations for each sectoral observation of production data.

measured at constant 1994 prices. It is divided between the total number of workers in the region to calculate value added per worker. At the time of publication, information disaggregated by sector and region was only available up to 2012 .

27 The Ministry of Labour and Employment Promotion (MTPE) kindly provided access to the absolute values of this indicator from the National Monthly Survey on Employment Variation (ENVME), allowing the registered employment rate (wage employment in firms with 10 or more workers) to be constructed as a proportion of total employment in each region. 


\section{Growth and formalization: the composition of growth does matter}

The first finding is that there is indeed a direct relationship between formalization and output growth. This can be seen in figure 4 , where the registered employment rate of each region is correlated with regional value added per worker. It can also be seen that this positive relationship has a high degree of variance, especially at higher levels of regional value added per worker (panel A of figure 4). It may also be noted that this relationship changes in the higher bands when the analysis excludes Moquegua (panel B of figure 4), a region where value added per worker is high because of the presence of copper mining, but at the same time informal employment is widespread because the bulk of its workforce is agricultural. This observation is important because it raises the possibility that there may be regional fixed effects that need controlling for.

FIGURE 4

Peru: relationship between the registered employment rate and value added per worker, by region, 2012

(Percentages)

A. All regions

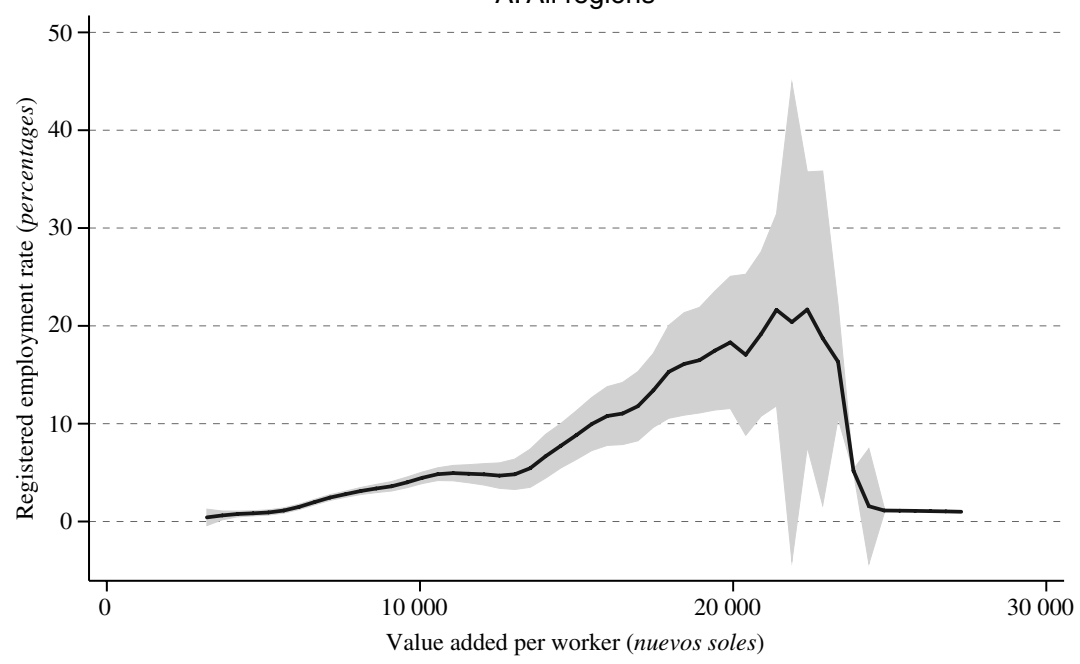

B. All regions except Moquegua

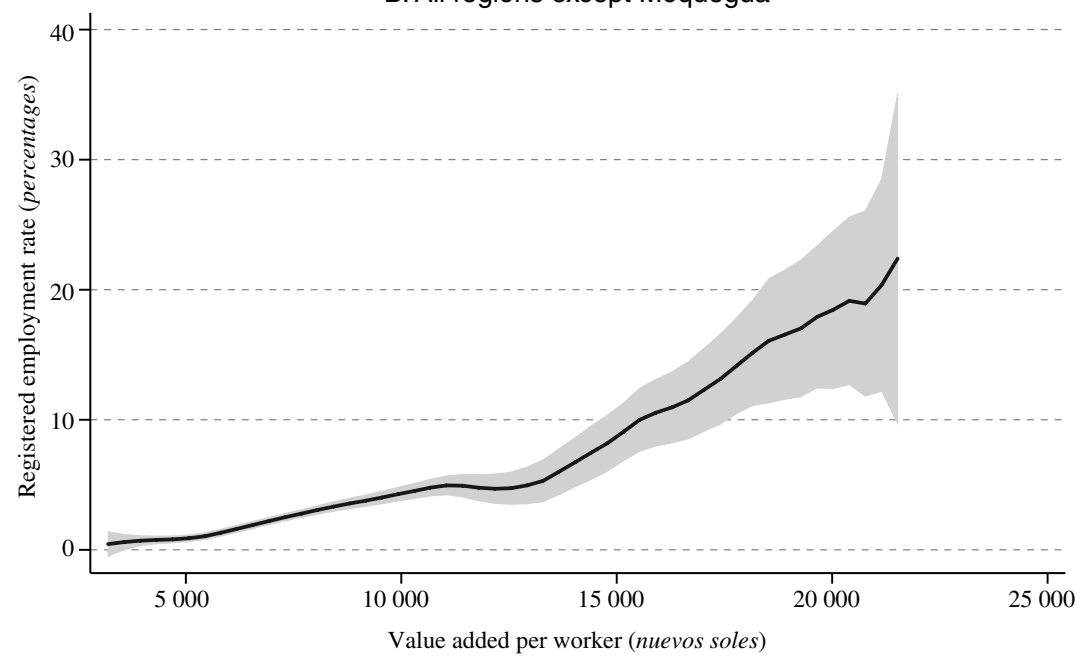

Source: Prepared by the author, on the basis of information from the National Institute of Statistics and Informatics (INEI) and the Ministry of Labour and Employment Promotion (MTPE). 
In any event, the simple correlation between the registered employment rate and value added per worker has a high degree of variance. Consequently, there must be other factors explaining formalization levels and growth in this indicator. One possibility is that not just economic growth in itself but also its composition is important for formalization. The hypothesis here would be that the type of economic growth, and particularly its sectoral composition, will affect formalization outcomes. In other words, the sectoral composition of growth is not neutral when it comes to formal job creation. Changing production patterns would help to shape and extend formal employment.

One way to approach this analysis is to break down the change in formality rates by identifying the contribution of sectoral change. ${ }^{28}$ First, the formal employment rate is defined as a weighted sum of sectoral rates:

$$
\tau_{t}=\sum \tau_{i t} \cdot \theta_{i t}
$$

28 This methodology is based on McMillan and Rodrik (2011). It has been used to analyse formalization by Bertranou and Casanova (2014) for Argentina and by Díaz (2014) for Peru.
Here, $\tau$ is the formal employment rate and is expressed as a weighted average of the formal employment rates in sectors $\tau_{i}$ and the share of sector $i$ in total employment, i.e., the sectoral structure of employment $\theta_{i}$ in each period. The difference in the formal employment rate in period $t$ and period $k$ can be written as follows:

$$
\Delta \tau_{i}=\sum \theta_{i, t-k} \Delta \tau_{i t}+\sum \tau_{i t} \Delta \theta_{i, t}
$$

In other words, the change in the formal employment rate can be expressed as the sum of two components. The first component (the rate effect) is meant to measure the contribution of changes in rates within each sector, keeping the employment structure unchanged. The second component (the composition effect) is meant to measure the change in the sectoral structure of employment, keeping the formal employment rate unchanged. The results of this exercise are shown in table 4, which uses the definition of the formal employment rate for 2002-2012. ${ }^{29}$

\footnotetext{
${ }^{29}$ In this exercise, use was made of the formal employment rate furnished by household surveys instead of the registered employment rate, as these provided sectorally disaggregated employment information.
}

Peru: decomposition of changes in the formal employment rate, 2002-2012

\begin{tabular}{|c|c|c|c|c|c|c|c|}
\hline & \multicolumn{2}{|c|}{ Formal employment rate } & \multicolumn{2}{|c|}{$\begin{array}{c}\text { Share of total } \\
\text { employment }\end{array}$} & \multicolumn{3}{|c|}{ Decomposition } \\
\hline & 2002 & 2012 & 2002 & 2012 & Rate effect & $\begin{array}{c}\text { Structure } \\
\text { effect }\end{array}$ & Sum \\
\hline \multicolumn{8}{|l|}{ Sector of activity } \\
\hline Farming and fishing & 5.4 & 7.4 & 33.3 & 24.6 & 0.5 & -0.5 & 0.0 \\
\hline Mining & 60.4 & 60.1 & 0.7 & 1.3 & -0.0 & 0.4 & 0.4 \\
\hline Manufacturing & 22.6 & 32.4 & 10.1 & 10.8 & 1.1 & 0.2 & 1.2 \\
\hline Construction & 12.8 & 23.9 & 3.7 & 5.9 & 0.7 & 0.3 & 0.9 \\
\hline Commerce & 13.1 & 18.8 & 17.4 & 17.9 & 1.0 & 0.1 & 1.1 \\
\hline Transport and communications & 13.1 & 17.5 & 5.8 & 7.3 & 0.3 & 0.2 & 0.5 \\
\hline Restaurants and hotels & 10.4 & 14.3 & 5.3 & 6.5 & 0.3 & 0.1 & 0.4 \\
\hline Other services & 46.5 & 54.5 & 23.7 & 25.7 & 2.0 & 0.9 & 3.0 \\
\hline Total & 19.6 & 27.1 & 100.0 & 100.0 & 5.8 & 1.7 & 7.5 \\
\hline
\end{tabular}
(Percentages)

Source: Prepared by the author, on the basis of National Institute of Statistics and Informatics (INEI), National Household Survey (ENAHO), various years.

Note: Sectors as classified by the International Standard Industrial Classification of All Economic Activities (ISIC). 
It can be seen that the 6.5 percentage point increase in formal employment that occurred in Peru between 2002 and 2012 breaks down into almost 6 percentage points deriving from the changes in rates within sectors and a further 1.7 percentage points deriving from the shift in the sectoral structure of employment. In other words, this shift accounts for over $20 \%$ of the increase in formal employment. The only sector to show no change in the composition effect is Farming and fishing, as it is the only one whose share of total employment fell. The Other services sector (which includes government) displays the largest rate and composition effects.

Meanwhile, employment may have undergone (and did undergo, according to a number of recent studies) major recomposition within sectors. Using data for 20022011, Díaz (2014) carries out a similar decomposition and finds that over $40 \%$ of the drop in informality is connected to the change in the structure of employment by firm size. Infante and Chacaltana (2014) add that this is because large and medium-sized enterprises displayed the greatest dynamism in respect of output, employment and productivity over the period.

This exercise only considers changes in the sectoral composition of employment, which means that a specific relationship still needs to be found between formalization and sectoral growth. To do this, the present study follows the methodological strategy used by Ravallion and Chen (2006) and Loayza and Raddatz (2006), who linked the composition of growth to the evolution of poverty. ${ }^{30}$ Essentially, what is offered here is an equation linking formalization to the sectoral composition of growth. Operationally, this means estimating an equation that relates changes in the registered employment rate at the region level with changes in sectoral output at that level. Given the earlier observation about Moquegua, the relationship is assumed to have regional fixed effects, and thus to take the following form:

$$
\Delta \tau_{j t}=\delta_{j}+\sum \delta_{i} \cdot s_{i j t} \cdot \Delta y_{i j t}+\varepsilon_{j t}
$$

Here, $\Delta \tau_{j t}$ is the change in the registered employment rate in region $j, \Delta y_{i j t}$ is the change in value added per worker in sector $i$ in region $j$, and $S_{i j t}$ is the share contributed by sector $i$ to the regional value added of

30 Ravallion and Chen (2006) use data from China to analyse the relationship between growth composition and poverty. Loayza and Raddatz (2006) use international country data and likewise relate poverty and the composition of growth. Arias-Vásquez, Lee and Newhouse (2012) extend this type of analysis to employment variables, although they do not analyse formality. region $j$. The $\delta_{j}$ coefficients are regional fixed effects. As indicated in the studies cited, the advantage of this specification is that if all the $\delta_{i}$ coefficients are equal, it is possible to add together changes in sectoral value added weighted by its share of regional value added. In this case, the equation becomes a simple regression between the change in the registered employment rate $\Delta \tau_{j t}$ and the change in regional value added $\Delta y_{j t}$. Thus, if the null hypothesis that the coefficients are equal cannot be rejected, then all that matters is the level of output and not its composition. Conversely, if the null hypothesis is rejected, the composition of growth is important. The focus in this article is on $\Delta \tau_{j t}$, since the aim is precisely to estimate the effects of the sectoral composition of growth on a territorially aggregated variable.

Table 5 presents two estimates. The first, shown in the first column of the table, is arrived at using the panel sample with the maximum likelihood (ML) method. The second column of the table contains the same estimation arrived at using pooled data with the ordinary least squares (OLS) method, which helps to verify whether the unbalanced panel affects the results, these being practically the same.

The coefficients that are significant and positive, with a $99 \%$ confidence level, are those for Farming and fishing, Commerce and Other services. The Restaurants and hotels coefficient is significant at $90 \%$. In all the other cases, the coefficients are not significant. In the case of Farming and fishing, the coefficient above 1 means that a proportional change of 1 percentage point in value added per worker in this sector implies growth of more than 1 percentage point in the registered employment rate at the region level. The same applies in the case of the Restaurants and hotels sector, while in the Commerce sector the coefficient is approximately equal to 1 .

In the case of the Other services sector (which includes government), the change is less than proportional. The test for equality of all coefficients indicates that the null hypothesis of all coefficients being equal is rejected with a 99\% confidence level. The hypothesis of all the coefficients equalling zero is likewise rejected. This confirms the hypothesis that growth has a greater effect in increasing the registered employment rate in some sectors than in others, and thus that the composition of growth matters. Following an additional test for the equality of coefficients by subgroups, the hypothesis that the coefficients for sectors with a significant coefficient are equal to one another cannot be rejected. The result is similar when sectors with a non-significant coefficient are grouped. 
Why do some sectors have a greater impact on formality than others? ${ }^{31}$ Panel A of figure 5 shows that the sectors obtaining significant coefficients (Farming and fishing, Commerce, Restaurants and hotels and Other services) are generally highly employmentintensive, i.e., the number of workers in them as a share of the regional employment total is high. The regional employment share of Farming and fishing ranges from $5 \%$ to $80 \%$, depending on the region. At the same time, these sectors evince lower levels of value added per worker, this being less than 20,000 nuevos soles a year

${ }^{31}$ Information on output by firm size is not available at the region level. in every region (panel B of figure 5). Furthermore, there is a low level of formality in these sectors. Accordingly, similar production changes probably entail larger changes in both formal employment rates and numbers of formalized workers when the registered employment rate is low at the outset. ${ }^{32}$

\footnotetext{
32 In addition, there is evidence that agricultural growth has been concentrated in certain regions of the country where there has been a recomposition of employment away from low-productivity sectors towards more productive ones. Some have associated these changes with the Agricultural Sector Promotion Act (Law No. 27360 of 2001), analysis of which is beyond the scope of this article. See Infante and Chacaltana (2014).
}

Peru: results of the regression between changes in the registered employment rate and sectoral growth

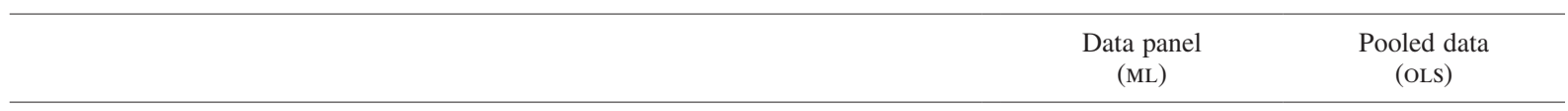

Change in the rate of output per worker in the sector weighted

by share of regional value added

\begin{tabular}{|c|c|c|}
\hline Farming and fishing & $\begin{array}{l}1.349 * * * \\
(0.244)\end{array}$ & $\begin{array}{l}1.414 * * * \\
(0.252)\end{array}$ \\
\hline Mining & $\begin{array}{l}-0.015 \\
(0.017)\end{array}$ & $\begin{array}{l}-0.020 \\
(0.018)\end{array}$ \\
\hline Manufacturing & $\begin{array}{c}0.068 \\
(0.153)\end{array}$ & $\begin{array}{c}0.113 \\
(0.167)\end{array}$ \\
\hline Construction & $\begin{array}{l}-0.011 \\
(0.152)\end{array}$ & $\begin{array}{l}-0.008 \\
(0.164)\end{array}$ \\
\hline Commerce & $\begin{array}{l}1.038 * * * \\
(0.295)\end{array}$ & $\begin{array}{l}0.990 * * \\
(0.313)\end{array}$ \\
\hline Transport and communications & $\begin{array}{c}0.541 \\
(0.298)\end{array}$ & $\begin{array}{c}0.557 \\
(0.327)\end{array}$ \\
\hline Restaurants and hotels & $\begin{array}{l}1.410 * \\
(0.552)\end{array}$ & $\begin{array}{l}1.406 * \\
(0.611)\end{array}$ \\
\hline Other services & $\begin{array}{l}0.681 * * * \\
(0.197)\end{array}$ & $\begin{array}{l}0.640 * * \\
(0.210)\end{array}$ \\
\hline Test 1: equality of coefficients & 0.00 & 0.00 \\
\hline Test 2: coefficients equal to 0 & 0.00 & 0.00 \\
\hline Test 3: equality of coefficients in employment-intensive sectors & 0.14 & 0.11 \\
\hline Test 4: equality of coefficients in non-employment-intensive sectors & 0.25 & 0.24 \\
\hline Adjusted $\mathrm{R}^{2}$ & & 0.28 \\
\hline Rho & 0.17 & \\
\hline Number of observations & 175 & 175 \\
\hline
\end{tabular}

Source: Prepared by the author.

Note: $(*)=$ significant at $10 \%,(* *)=$ significant at $5 \%$ and $(* *)=$ significant at $1 \%$.

Standard deviation in parentheses.

Employment-intensive sectors: Farming and fishing, Commerce, Restaurants and hotels and Other services.

ML: Maximum likelihood; oLs: Ordinary least squares. 
FIGURE 5

Peru: regional distribution of employment intensity and value added per worker, by sector, 2002-2012

A. Employment intensity, 2002-2012

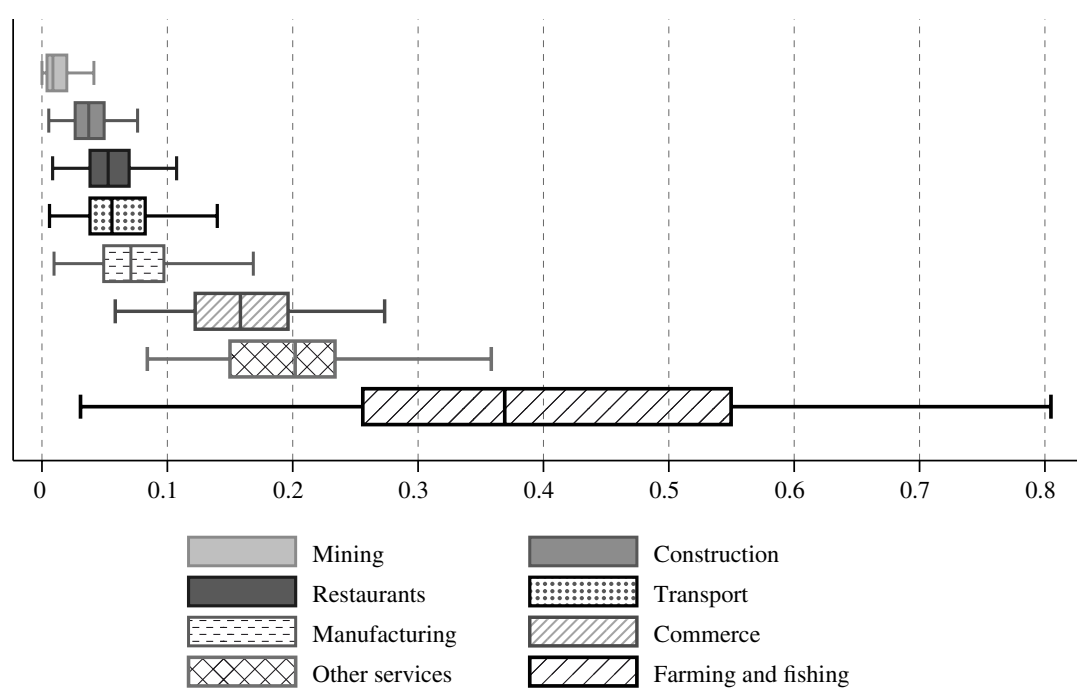

B. Value added per worker, 2002-2012 (nuevos soles)

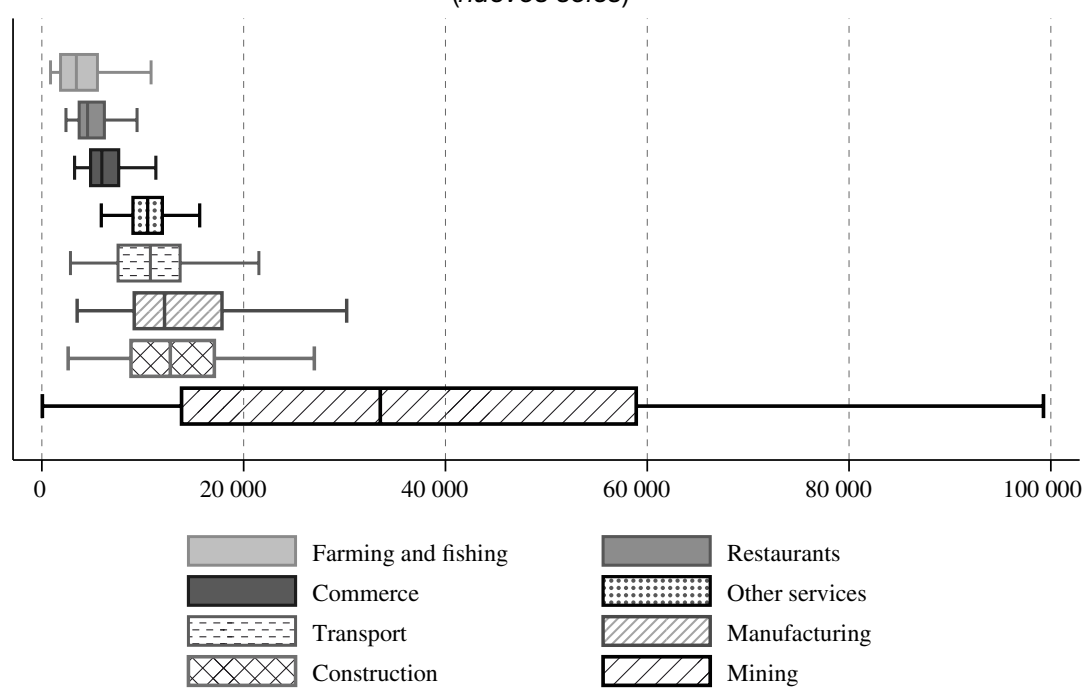

Source: Prepared by the author, on the basis of National Institute of Statistics and Informatics (INEI), National Household Survey (ENAHO), various years

Note: Employment in sector $i$ in region $j$ as a share of total employment in region $j$. Output per worker in each region is measured in 1994 nuevos soles. 


\section{Formalization in 2002-2012: explanatory factors}

This subsection conducts a combined analysis of a number of factors that may have influenced the formalization process in Peru, as observed between 2002 and 2012. Each factor could have a significant individual relationship with formality, but it is important to check whether this significance is maintained when competing variables or hypotheses are controlled for. Accordingly, it is important to carry out a combined analysis of economic factors (size and composition) and of variables associated with legal or institutional changes that came about in the period.

In accordance with the analysis of the previous sections, four possible factors highlighted by the literature and by recent academic and political debate are evaluated:

(i) Economic growth. In the period of analysis, GDP grew by $6 \%$ a year, meaning that the economy expanded by $70 \%$ in real terms. Regional value added per worker also rose in this period.

(ii) The change in the production structure, given the finding that the sectoral composition of growth matters. In particular, it is worth carrying out a comparative evaluation of the role that may have been played by the rising output share of the most employment-intensive sectors (Farming and fishing, Commerce, Restaurants and hotels and Other services), identified earlier as making a significant contribution.

(iii) Regulatory changes. There was a major labour market reform whose specific goal, according to its authors, was to reduce labour costs by creating a special regime for smes. The reform took place in 2003 and was extended in 2008 (coming into effect in 2009). To gauge the effect of these regulatory changes on formalization, in the context of the database used here, weighted average labour costs were calculated for each region. The structure of employment by firm size was used for this so that the relevant labour costs could be weighted (see figure 3 ).

(iv) Changes in the ability of the State to enforce its rules. As mentioned, there were major changes in this respect too, making it hard to obtain statistics that are comparable over time. Accordingly, the number of inspection orders completed by MTPE per 1,000 workers was used as a proxy for the likelihood of detection. ${ }^{33}$ The coverage of inspections is fairly low in Peru and is largely confined to formal firms and wage workers. The expectation is that an increase in the likelihood of detection would improve the registered employment rate.

Figure 6 shows simple partial correlations for these variables in variations. A greater correlation is observed between formalization and economic variables than between formalization and reform variables (change in average regional labour costs) or inspection variables (change in inspection orders per 1,000 workers). In particular, the correlation between formalization and regional growth (change in regional value added per worker) is high, showing that the quantum of growth is very important. The correlation between formalization and changes in the share of employment-intensive sectors is also positive, which is consistent with the previous finding that sectoral growth is important.

\footnotetext{
${ }^{33}$ Inspection data were obtained from the statistical yearbooks of the Ministry of Labour and Employment Promotion (MTPE).
}
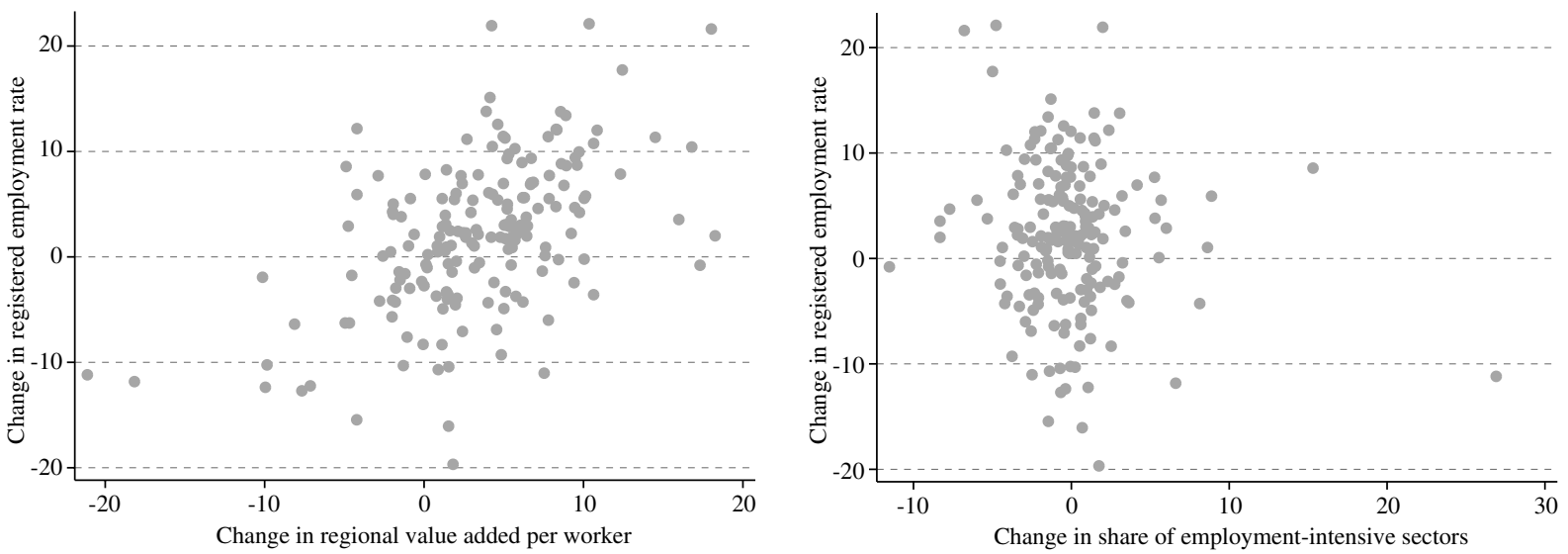
Figure 6 (concluded)
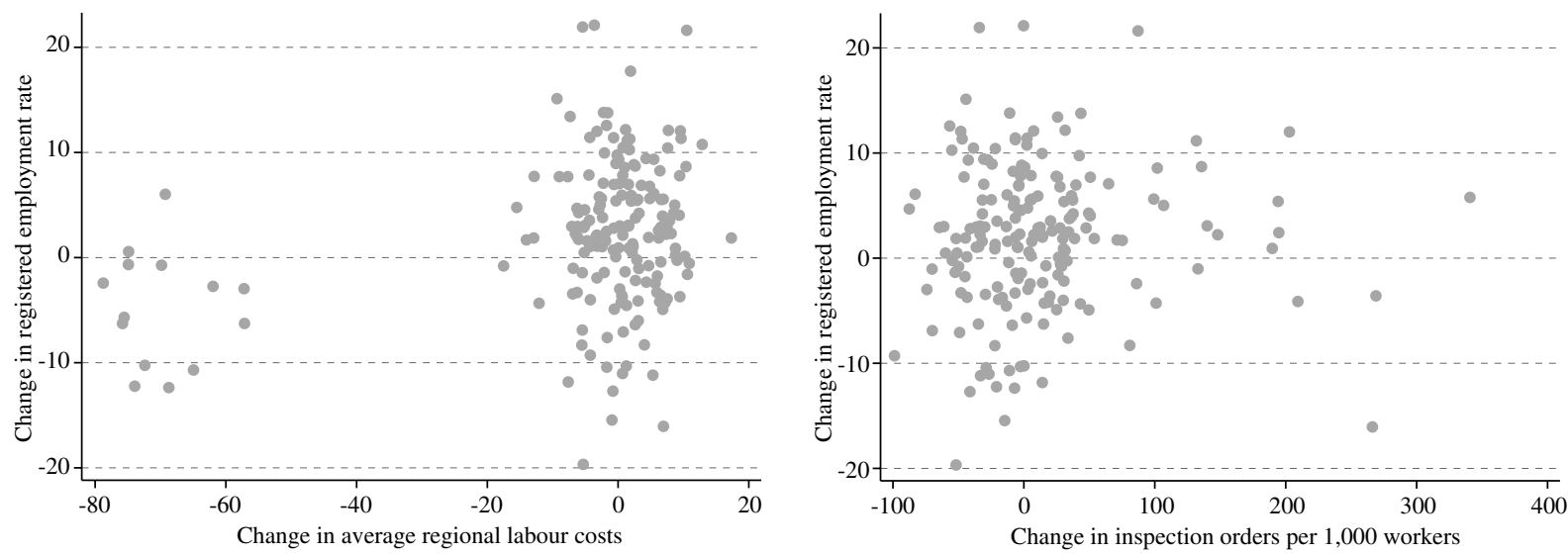

Source: Prepared by the author, on the basis of information from the National Institute of Statistics and Informatics (INEI), the Ministry of Labour and Employment Promotion (MTPE), the National Household Survey (ENAHO) and Law No. 30288.

Note: Employment-intensive sectors: Farming and fishing, Commerce, Restaurants and hotels and Other services.

All these factors were then analysed in combination using a multiple regression analysis. ${ }^{34}$

$$
\Delta \tau_{j t}=\beta_{j}+\beta_{1} \Delta y_{j t}+\beta_{2} \Delta s_{j t}^{\text {high }}+\beta_{3} \Delta r_{j t}+\beta_{4} \Delta f_{j t}+\xi_{j t}
$$

In this case, $\beta_{j}$ are the regional fixed effects, $\Delta y_{j t}$ is the growth of regional value added per worker, $s_{j t}^{\text {high }}$ is the change in labour-intensive sectors' share of regional value added, $\Delta r_{j t}$ is the proxy for the introduction of the Promotion and Formalization of Micro and Small Enterprises Act and $\Delta f_{j t}$ is the change in the rate of inspection orders per 1,000 workers. The results of this exercise are shown in table 6, which presents various estimates that progressively incorporate the different variables.

Panel (a) of table 6 uses a regression in variations. First, it relates the change in the registered employment rate with the growth of regional value added per worker. The coefficient is significant at $1 \%$ (model 1 of table 6). To this regression is then added a variable representing growth in employment-intensive sectors' share of regional value added. Its coefficient is also significant at $5 \%$, and the significance of regional value added per

\footnotetext{
34 The multiple regression analysis is presented here solely for the purpose of carrying out a controlled analysis of the effects of different variables on registered employment, and is not meant to evaluate their individual impact. There are studies that have set out to evaluate some of these factors separately. Evaluating all these factors in combination would require a multiple treatment analysis, which is beyond the scope of this article.
}

worker is maintained (model 2). The third step is to add in the proxy for the introduction of the Promotion and Formalization of Micro and Small Enterprises Act (the change in regionally weighted average labour costs); its effect is found to be non-significant, even when the significance of the previous variables is maintained (model 3). Lastly, the variable for inspection changes is added; with the previous results unaltered, its introduction proves non-significant (model 4). Interestingly, the adjusted $R^{2}$ adjustment coefficient is 0.31 when regional value added per worker alone is considered (model 1), rising to 0.35 when the change in the composition of growth is added (model 2).

As an alternative, panel (b) of table 6 uses dummy variables as proxies for the institutional variables. In this case, one dummy is used for the year 2003, when the employment regime for microenterprises was set up (model 3), and another one for 2009, when the extension of this law to firms with up to 100 workers came into effect (model 4). As a proxy for the effect of the "electronic payroll" system, ${ }^{35}$ a dummy was also created for 2008 ,

\footnotetext{
35 The electronic payroll system is an electronic procedure whereby employers with three or more workers have to submit monthly reports to the Office of the National Superintendent of Tax Administration (SUNAT) with information on their workers, pensioners, service providers, trainees, outside staff and dependants. The report used to be made directly to the Ministry of Labour. This administrative change has increased the ability of the Ministry to supervise and verify compliance with employment obligations, as it can use the installed capacity and detection capabilities of SUNAT (ILO, 2014b).
} 
the year its use became compulsory (model 5). ${ }^{36}$ The analysis of these variables, controlling for the growth of regional value added per worker and sectoral growth, yielded non-significant coefficients for them.

These findings imply that the increase in value added per worker in the regions proved a decisive factor in the rise of the registered employment rate in Peru. The growth

36 Because the changes are permanent, dummies with a value of 1 were used for the year concerned and following years. The dummies are nationwide because the regime does not vary by subnational region. of certain sectors, such as the more employment-intensive ones, also adds explanatory power to this process. The variables associated with labour market reform do not prove significant, in contrast to the scale of the changes this entailed. Much the same can be said of the measures to strengthen inspections, which remain weak despite the changes made. ${ }^{37}$

37 The National Labour Inspection Authority (sUNAFIL) was set up in 2013 to strengthen the inspection service.

TABLE 6

Multiple regression results, 2002-2012

a. Variables for economic growth and institutional changes (in variations)

\begin{tabular}{|c|c|c|c|c|}
\hline Dependent: variation in the registered employment rate & Model 1 & Model 2 & Model 3 & Model 4 \\
\hline Variation in regional value added per worker & $\begin{array}{l}0.633^{* * * *} \\
(0.068)\end{array}$ & $\begin{array}{l}0.781 * * * \\
(0.079)\end{array}$ & $\begin{array}{l}0.759^{* * *} \\
(0.079)\end{array}$ & $\begin{array}{l}0.747 * * * \\
(0.080)\end{array}$ \\
\hline Variation in the regional output share of labour-intensive sectors & & $\begin{array}{l}0.493^{* * * *} \\
(0.141)\end{array}$ & $\begin{array}{l}0.464 * * \\
(0.141)\end{array}$ & $\begin{array}{l}0.464 * * \\
(0.141)\end{array}$ \\
\hline Variation in regional labour costs & & & $\begin{array}{c}0.038 \\
(0.022)\end{array}$ & $\begin{array}{c}0.038 \\
(0.022)\end{array}$ \\
\hline $\begin{array}{l}\text { Variation in the rate of inspection orders completed per } 1000 \text { employees, } \\
\text { by region }\end{array}$ & & & & $\begin{array}{c}0.001 \\
(0.001)\end{array}$ \\
\hline F test & 86.3 & 51.9 & 36.0 & 27.3 \\
\hline Prob > F ( $p$-value $)$ & 0.00 & 0.00 & 0.00 & 0.00 \\
\hline Adjusted $\mathrm{R}^{2}$ & 0.314 & 0.354 & 0.361 & 0.361 \\
\hline No. of observations & 186 & 186 & 186 & 186 \\
\hline
\end{tabular}

b. Variables for economic growth and institutional changes (dummies)

\begin{tabular}{|c|c|c|c|c|c|}
\hline Dependent: variation in the registered employment rate & Model 1 & Model 2 & Model 3 & Model 4 & Model 5 \\
\hline Variation in regional value added per worker & $\begin{array}{l}0.633 * * * \\
(0.068)\end{array}$ & $\begin{array}{l}0.781 \text { *** } \\
(0.079)\end{array}$ & $\begin{array}{l}0.886^{* * * *} \\
(0.098)\end{array}$ & $\begin{array}{l}0.918 \text { *** } \\
(0.098)\end{array}$ & $\begin{array}{l}0.924 * * * \\
(0.101)\end{array}$ \\
\hline Variation in the regional value added share of labour-intensive sectors & & $\begin{array}{l}0.493^{* * * *} \\
(0.141)\end{array}$ & $\begin{array}{l}0.588 * * * \\
(0.150)\end{array}$ & $\begin{array}{l}0.661 \text { *** } \\
(0.153)\end{array}$ & $\begin{array}{l}0.667 * * * \\
(0.155)\end{array}$ \\
\hline
\end{tabular}

Dummy variables associated with small and medium-sized enterprise employment regimes

Year 2003 (microenterprise regime)

$\begin{array}{lll}-0.949 & -0.133 & -0.068 \\ (0.538) & (0.668) & (0.706) \\ & -1.778 & -1.377 \\ & (0.874) & (1.629) \\ & & -0.49 \\ & & (1.68)\end{array}$

Dummy variables associated with stronger inspections

Year 2008 (electronic payroll)

F test

Prob $>$ F ( $p$-value)

Adjusted $\mathrm{R}^{2}$

No. of observations

$\begin{array}{ccccc}86.3 & 51.9 & 36.0 & 28.5 & 22.7 \\ 0.00 & 0.00 & 0.00 & 0.00 & 0.00 \\ 0.314 & 0.354 & 0.361 & 0.372 & 0.369 \\ 186 & 186 & 186 & 186 & 186\end{array}$

Source: Prepared by the author, on the basis of information from the National Institute of Statistics and Informatics (INEI), the Ministry of Labour and Employment Promotion (MTPE), the National Household Survey (ENAHO) and Law No. 30288.

Note: $*$ significant at $10 \%, * *$ significant at $5 \%$ and $* * *$ significant at $1 \%$.

Standard deviation in parentheses. Employment-intensive sectors: Farming and fishing, Commerce, Restaurants and hotels and Other services. 


\section{V}

\section{Conclusions}

Peru recorded high growth rates in the 2000s and early 2010s. This period of economic growth brought down unemployment, which reached a historic low of less than $4 \%$ nationally in 2013. There was also a significant reduction in the poverty rate, which more than halved from its level of the early 2000s, something that certainly indicates an improvement in incomes, although it also brings into relief the role of redistributive social policy and its connection to the greater availability of fiscal resources. In turn, the percentage of formal employment rose from $20.1 \%$ to $26.3 \%$ between 2007 and 2012. This is remarkable progress, even though the rate of informal employment is still very high.

The present article has analysed this formalization process and sought to identify the factors that could explain it. Much of the foregoing discussion has concentrated on certain specific relationships, particularly the one between informality and labour market reform. The goal here was to identify the contribution of each element as part of an integrated approach in which it was assumed that different policies may have some explanatory power. The Peruvian case is an interesting one for this purpose, since different factors that could in theory explain the process came together in the period of analysis, examples being economic growth, labour market reform (with the creation of a special regime that reduced employment costs for most of the labour market) and improvements in the inspection system. All these elements have been flagged up by different theories as factors explaining informality, and thence formality.

The analysis was carried out in two stages. First, the effects of sectoral growth on formalization were estimated on the basis of a model originally developed to measure the effects of sectoral growth on poverty. The findings show that the sectoral effects are differentiated, which bears out the hypothesis that the composition of growth matters for formalization. In particular, economic growth in the most employment-intensive sectors (Farming, Commerce, Other services and, to an extent, Restaurants and hotels) accounts for the formalization seen. Then, considering that formalization is a process with multiple causes, a comparative analysis of the factors that might have been behind the growth in the registered employment rate between 2002 and 2012 were analysed. The results indicate that a key element was the growth in regional value added per worker. Also significant was the growth in the share of value added per worker accounted for by the most employment-intensive and at the same time least productive sectors, as this indicates that their value added per worker grew more quickly than regional value added per worker. The variables associated with labour market reform and inspection changes did not have significant effects.

These findings are consistent with the fact that at least two of every three workers with an informal job in Peru are employed in informal economic units which are not registered as businesses or for tax purposes, and that economic units in the informal sector have productivity levels an eighth those of the formal sector. In these circumstances, it is understandable that only variables associated with growth, and particularly growth in lower-productivity sectors, should have significant coefficients. This implies that the formalization of employment presupposes formalization of the economic units where informal jobs are generated. Consequently, the emphasis on reducing employment costs for smes probably needs to be replaced with a greater stress on enhancing the benefits of formality, such as access to larger markets, financing, business development services and security, among others.

\section{Bibliography}

Acemoglu, D. (2001), "Good jobs versus bad jobs", Journal of Labor Economics, vol. 19, No. 1, Chicago, University of Chicago Press.

Arias-Vásquez, F.J., J.N. Lee and D. Newhouse (2012), The Role of Sectoral Growth Patterns in Labor Market Developments, Washington, D.C., World Bank.

Berg, J. (2010), "Laws or luck? Understanding rising formality in Brazil in the 2000s", MPRA Paper, No. 43608, Munich, University Library of Munich.
Bertranou, F. and L. Casanova (2014), Informalidad laboral en Argentina, Buenos Aires, International Labour Organization (ILO).

Bhagwati, J. and A. Panagriva (2013), "Why growth matters: how economic growth in India reduced poverty and lessons for other developing countries", PublicAffairs, New York.

Chacaltana, J. (2008), "Una evaluación del régimen laboral especial para la microempresa en Perú, al cuarto año de vigencia”, Lima, International Labour Organization (ILO), unpublished. 
(2007), Desafiando al desierto: realidad y perspectivas del empleo en Ica, Lima, Center for Development and Participation Studies (CEDEP).

(2001), "Reforma en la contratación y el despido en el Perú de los noventa", Revista Economía, vol. 24, No. 48, Lima, Catholic University of Peru.

Chang, H.-J. (2007), Bad Samaritans. Rich Nations, Poor Policies, and the Threat of the Developing World, London, Random House.

Chong, A., J. Galdo and J. Saavedra (2007), Informality and Productivity in the Labor Market: Peru 1986-2001, Washington, D.C., InterAmerican Development Bank (IDB).

De Janvry, A. and E. Sadoulet (2010), "Agricultural growth and poverty reduction: additional evidence", World Bank Research Observer, vol. 25, No. 1, Oxford University Press.

De Soto, H. and others (1986), El otro sendero: la revolución informal, Lima, El Barranco.

Díaz, J.J. (2014), "Formalización empresarial y laboral", Hacia un desarrollo inclusivo. El caso de Perú, R. Infante and J. Chacaltana (eds.), Santiago, Economic Commission for Latin America and the Caribbean (ECLAC)/International Labour Organization (ILO).

Doeringer, P.B. and M.J. Piore (1971), International Labor Markets and Manpower Analysis, Heath Lexington Books.

El Peruano (2014), "Ley N 30288", Lima, 16 December.

Fields, G. (1990), "Labour market modeling and the urban informal sector: theory and evidence", The Informal Sector Revisited, D. Turnham, B. Salomé and A. Schwarz (eds.), Paris, Organization for Economic Cooperation and Development (OECD).

Hart, K. (1972), Employment, Income and Inequality: A Strategy for Increasing Productive Employment in Kenya, Geneva, International Labour Organization (ILO).

ILo (International Labour Organization) (2015), Transition from the Informal to the Formal Economy Recommendation, Geneva, International Labour Conference.

(2014), 2014 Labour Overview. Latin America and the Caribbean, Lima.

(2014b), "Trends in informal employment in Peru: 2004-

2012", Notes of Formalization, Lima.

(2013), Measuring Informality: A Statistical Manual on the Informal Sector and Informal Employment, Geneva.

(2002), Decent Work and the Informal Economy, 90th Session of the International Labour Conference, Geneva.

INEI (National Institute of Statistics and Informatics) (2014), Producción y empleo informal en el Perú. Cuenta satélite de la economía informal 2007-2012, Lima.

(2013), Compendio estadístico del Perú, 2013, Lima.

Infante, R. and O. Sunkel (2012), "La heterogeneidad de la estructura productiva latinoamericana", Santiago, Economic Commission for Latin America and the Caribbean (ECLAC).

Infante, R. and J. Chacaltana (2014), Hacia un desarrollo inclusivo. El caso de Perú, Santiago, Economic Commission for Latin America and the Caribbean (ECLAC)/International Labour Organization (ILO).

Infante, R., J. Chacaltana and M. Higa (2014), "Aspectos estructurales del desempeño macroeconómico del Perú. Situación actual, perspectivas y políticas", Hacia un desarrollo inclusivo. El caso de Perú, R. Infante and J. Chacaltana (eds.), Santiago, Economic Commission for Latin America and the Caribbean (ECLAC)/International Labour Organization (ILO).

Jaramillo, M. (2013), Employment Growth and Segmentation in Peru, 2001-2011. Country Case Study on Labour Market Segmentation, Geneva, International Labour Organization (ILO).

Kaldor, N. (1961), Capital Accumulation and Economic Growth, Paris, United Nations Educational, Scientific and Cultural Organization (UNESCO).
Kanbur, R. (2009), "Conceptualizing informality: regulation and enforcement", Indian Journal of Labour Economics, vol. 52, No. 1, Cambridge, Massachusetts, Women in Informal Employment: Globalizing and Organizing (WIEGo).

León, J. and R. Cermeño (1990), Las interrelaciones entre los sectores formal e informal en Lima Metropolitana: el caso de la industria, Lima, Catholic University of Peru.

Levy, S. (2008), Good Intentions, Bad Outcomes. Social Policy, Informality, and Economic Growth in Mexico, Washington, D.C., Brooking Institution Press.

Lewis, A. (1954), "Economic development with unlimited supplies of labour", The Manchester School, vol. 22, No. 2, Wiley.

Loayza, N. (2013), Causas y consecuencias de la informalidad en el Perú, Lima, Central Reserve Bank of Peru.

Loayza, N. and C. Raddatz (2006), "The composition of growth matters for poverty alleviation", Policy Research Working Papers, Washington, D.C., World Bank.

Machado, R. (2012), "La economía informal en el Perú: magnitud y determinantes (1980-2011)", Apuntes del CIUP, vol. 41, No. 74, Lima, University of the Pacific.

Maloney, W.F. (1999), "Does informality imply segmentation in urban labor markets? Evidence from sectoral transitions in Mexico", The World Bank Economic Review, vol. 13, No. 2, Oxford University Press.

McMillan, M.S. and D. Rodrik (2011), "Globalization, structural change and productivity growth", NBER Working Paper, No. 17143, Cambridge, Massachusetts, National Bureau of Economic Research (NBER).

Ministry of Economic Affairs and Finance (2011), Marco macroeconómico multianual 2012-2014, Lima.

Perry, G. and others (2007), Informality: Exit and Exclusion, Washington, D.C., World Bank.

Portes, A., M. Castells and L. Benton (1989), The Informal Economy. Studies in Advanced and Less Developed Countries, Baltimore, Johns Hopkins University Press.

Ravallion, M. and S. Chen (2006), China's (Uneven) Progress against Poverty, Washington, D.C., World Bank.

Ray, D. (2010), "Uneven growth: a framework for research in development economies", Journal of Economic Perspectives, vol. 24, No. 3, Nashville, Tennessee, American Economic Association.

Solimano, A. (1996), Road Maps to Prosperity. Essays on Growth and Development, Ann Arbor, The University of Michigan Press.

Távara, J., E. González de Olarte and J.M. del Pozo (2014), "Heterogeneidad estructural y articulación productiva en el Perú: evolución y estrategias", Hacia un desarrollo inclusivo. El caso de Perú, R. Infante and J. Chacaltana (eds.), Santiago, Economic Commission for Latin America and the Caribbean (ECLAC)/International Labour Organization (ILO).

Tello, M. (2012), "Labor productivity in Peru: 1997-2007”, Journal of CENTRUM Cathedra, vol. 5, No. 1.

Tokman, V.E. (1978), "An exploration into the nature of informal-formal sector relationships", World Development, vol. 6, No. 9-10, Amsterdam, Elsevier.

Verdera, F. (2014), "Do limits exist to informality growth in South America? A preliminary exploration", The Informal Economy in Developing Countries, J.-P. Cling and others (eds.), New York, Routledge.

WIEGO (Women in Informal Employment: Globalizing and Organizing) (2012), The Informal Economy: Definitions, Theories and Policies, Cambridge, Massachusetts.

Yamada, G. (1996), "Urban informal employment and self employment in development countries: theory and evidence", Economic Development and Cultural Change, vol. 44, No. 2, Chicago, The University of Chicago Press. 